University of Rhode Island

DigitalCommons@URI

9-23-2015

Imported Inequality? Immigration and Income Inequality in the American States

Ping Xu

University of Rhode Island, pingxu@uri.edu

James C. Garand

Ling Zhu

Follow this and additional works at: https://digitalcommons.uri.edu/psc_facpubs

The University of Rhode Island Faculty have made this article openly available.

Please let us know how Open Access to this research benefits you.

This is a pre-publication author manuscript of the final, published article.

Terms of Use

This article is made available under the terms and conditions applicable towards Open Access

Policy Articles, as set forth in our Terms of Use.

Citation/Publisher Attribution

$\mathrm{Xu}$, Ping, et al. "Imported Inequality? Immigration and Income Inequality in the American States." State Politics \& Policy Quarterly, vol. 16, no. 2, June 2016, pp. 147-171, doi:10.1177/1532440015603814.

Available at: http://dx.doi.org/10.1177/1532440015603814

This Article is brought to you for free and open access by the Political Science at DigitalCommons@URI. It has been accepted for inclusion in Political Science Faculty Publications by an authorized administrator of DigitalCommons@URI.For more information, please contact digitalcommons-group@uri.edu. 


\title{
IMPORTED INEQUALITY? IMMIGRATION AND INCOME INEQUALITY IN THE AMERICAN STATES
}

\author{
Ping $\mathrm{Xu}$ \\ Assistant Professor \\ Department of Political Science \\ 130 Washburn Hall \\ University of Rhode Island \\ Kingston, RI 02881-0817 \\ Phone: 401-874-4053 \\ Email: pingxu@uri.edu \\ James C. Garand \\ Emogene Pliner Distinguished Professor \\ R. Downs Poindexter Professor \\ Department of Political Science \\ 205 Stubbs Hall \\ Louisiana State University \\ Baton Rouge, Louisiana 70803 \\ Phone: 225-578-2548 \\ Email: pogara@lsu.edu \\ Ling Zhu \\ Assistant Professor \\ Department of Political Science and \\ The Master of Public Administration Program \\ 436 Philip G. Hoffman Hall \\ University of Houston \\ Houston, TX 77204 \\ Phone: 713-743-2649 \\ Email: Izhu4@central.uh.edu
}




\title{
IMPORTED INEQUALITY? IMMIGRATION AND INCOME INEQUALITY IN THE AMERICAN STATES
}

\begin{abstract}
In this paper we use data from the American states from 1996 to 2008 to explore the effects of immigration on income inequality. Empirical evidence from both static and dynamic models shows that the foreign-born population has a strong positive effect on state-level income inequality, even when we control for a range of federal and state political and economic contextual variables. We also find that the positive relationship between immigration and state income inequality is driven primarily by low-skill immigrants (rather than high-skill immigrants), and we provide some evidence that high-skill immigrants lower income inequality for some segments of the income distribution. We conclude that immigrationparticularly low-skilled immigration-has an important effect on income inequality in the American states.
\end{abstract}


The past three decades have seen a substantial rise in income inequality in the United States. Since the 1970s, the income gap between the rich and the poor has escalated rapidly and exceeded that of most other industrial democracies (Bartels, 2008; Jacobs, 2005; Nathan. Kelly, 2009). The ever-growing income disparities in the United States have profound political consequences. Arguably, it leads to party polarization at the national and subnational levels (Garand, 2010; McCarty, Poole, and Rosenthal, 2006), challenges the fundamental democratic principles of equal citizenship and government responsiveness to the majority (Bartels, 2009), and depresses political participation (Jacobs, 2005; Solt, 2008).

In the American context, political scientists have renewed their interests in using the political economy framework to study how two major forces-markets and politics-shape income inequality in the American democracy (Soss and Jacobs, 2010). On one hand, political economists who emphasize the role of market forces attribute increased income inequality primarily to changes in labor market institutions (Levy and Temin, 2007), the economic impact of trade-liberalization (Richardson, 1995), immigration (Borjas 1994), and the mismatch between education and the technological needs of the American economy (Goldin and Katz, 2008). On the other hand, scholars who underscore the institutional determinants of income inequality focus on the ideology of political incumbents (Bartels, 2008; McCarty et al., 2006), various neoliberal policies such as tax reforms, minimum wage and welfare policies (Bartels, 2008; Hero and Preuhs, 2007), the unequal political representation of the high- and low-income groups (Hacker and Pierson, 2010), and the decline of the American civic society (Putnam, 2000; Skocpol, 2003).

Among those political and economic determinants of inequality, immigration has been one of the most controversial. Based on analyses of individual-level wage data, economists suggest that immigration has a positive effect on wage inequality in popular immigrant-receiving countries such as the United States (Borjas 1994; 2000; Hatton and Williamson 1998; Williamson 1997), while others argue that immigrants have little effect on domestic labor market outcomes such as wages, unemployment rates, and wage inequality (Altonji and Card, 1991; Card, 1990, 2007, 2009). Political scientists have recently studied the 
political determinants of income inequality and found that political partisan control and ideological orientation of governments play an important role in influencing inequality.

In this paper, we explore systematically the effects of immigration on income inequality in the American states, all-the-while accounting for the effects of the economic and political factors that help to shape levels of income inequality. We maintain that much of what we already know about immigration and income inequality is limited by the predominant focus on individual-level wage and labor market outcomes, but even these individual-level studies have generated mixed findings. To date relatively little is known about the linkage between these two concepts at the aggregate level. Moreover, the expanding American politics literature on income inequality is typically based on national-level data. Studies at the state-level have documented the importance of state political context in shaping inequality, but these studies have typically failed to take into account the effects of immigration.

To fill in this gap we consider how immigration and state political environment has combined to influence variation in income inequality across the 50 American states over time. We test hypotheses about immigration and income inequality using both static and dynamic modeling based on pooled crosssectional time-series data for 50 American states from 1996 to 2008. Our project makes three contributions to understanding the political economy of income inequality in American states. First, our research is one of the first attempts to study the relationship between immigration and income inequality at the state level over an extensive time frame. We focus our attention on the effects of the general foreign-born population, but we also consider the effects of three specific immigrant groups-i.e., newly admitted legal permanent residents, low-skill immigrants, and high-skill immigrants—on income inequality. We find that the foreign-born population and, particularly, low-skill immigrants have a strong positive effect on income inequality. Second, we go beyond the static association between immigration and income inequality found in much of the scholarly literature by considering more complex dynamics. We find that both the foreign-born population and low-skill immigrants have positive long-term effects on 
state-level income inequality. Third, both the foreign-born population and low-skill immigrants also have a positive effect on the relative income ratios between high- and lower- to middle-income groups (i.e., $90 / 10,90 / 20,90 / 30,90 / 40$, and 90/50 income ratios), while high-skill immigrants attenuate the relative income ratios for groups in some parts of the income distribution. These findings verify our argument that immigrants in the U.S. are bifurcated in their skills, which contributes to the rising income inequality.

Finally, by focusing on state-level income inequality, we find that the dynamics of income inequality at the subnational level differ from those observed at the national level. Kelly and Enns (2010) find that income inequality at the national level is self-reinforcing through the ways in which the poor and the rich respond to changes in inequality. On the other hand, our findings suggest that (1) state-level income inequality is self-correcting, which verifies Kelly and Witko's (2012) argument that American state governments are more active in fighting income inequality, and (2) compared to the federal government state governments have more means to do so. When considered together, these findings suggest the critical role that states have in shaping income inequality in the American democracy.

\section{IMMIGRATION, LABOR MARKETS, POLICIES, AND INCOME INEQUALITY}

The U.S. has been thought of for some time as a country of immigrants, and contemporary experience reinforces that perception. At its peak time during the 1910s, the U.S. maintained a foreign-born population of almost $15 \%$. After declining to a low of $4.7 \%$ in the early 1970 s, the foreign-born population increased to approximately $13 \%$ of the total U.S. population in 2010 , and in the past decade the U.S. has admitted about 1.3 million new arrivals every year (Camarota, 2012). What makes today's immigration issue dramatically different from a century ago is the demographic composition of the immigrant population. During the immigration wave between 1880 and 1921, immigrants from southern and Eastern Europe resembled the American population prevailing at the time. Yet in recent years the demographic and country-of-original makeup of the American immigration population has changed. As of 2010 about 53\% of immigrants are from Mexico, Central America, the Caribbean, or South America (Camarota, 2012); 
further, about $59 \%$ of the illegal immigrant population in the United States in 2011 is from Mexico, with another 14\% from El Salvador, Guatemala, and Honduras (Hoefer, Rytina, and Baker, 2011). Many immigrants come to the United States with relatively low education, weak English skills, lower socioeconomic background, and other attributes that put them at a competitive disadvantage in the labor market when compared to native-born Americans (Camarota, 2012; Card, 2009; Passel, 2005). For instance, according to U.S. Census Bureau data from 2009, 89\% of native-born Americans have a highschool degree or more, while only $68 \%$ of the foreign-born population has a high-school degree or more (Ryan and Siebens, 2012). Moreover, Reeves and Venator (2014) use 2011 CPS data to make the point that immigrants from Latin American countries are much more likely than immigrants from other regions of the world to have lower education levels; while $56 \%$ of first-generation immigrants from all countries have a high-school education or less, the same is true for $73 \%$ of first-generation immigrants from Latin American countries. Clearly, immigrants enter the American labor market with lower average education levels than the native-born population, and this is particularly true for the current configuration of the immigrant population that has a higher share of immigrants from Latin American countries.

\section{Historical evidence in comparative politics}

Economists have studied the linkage between immigration and inequality for some time. They have observed the migration waves in the late $19^{\text {th }}$ century and found that inequality increased in resource-rich and immigrant-receiving countries such as Argentina, Australia, Canada, and the United States. They speculate that as low-skill immigrants "flooded the receiving countries' labor markets at the bottom of the skill ladder, they must have lowered unskilled wages relative to those of skilled artisans and educated white-collar workers and relative to land rents" (Williamson 1997: 125). This same pattern was found in immigrant-importing countries in the second half of the $20^{\text {th }}$ century. Low-skill immigrants increased receiving countries' low-skill labor supply and consequently increased inequality (Hatton and Williamson (1997). Alderson and Nielsen (2002) find that immigration has a moderately positive effect on income 
inequality in the 16 OECD countries, while Moore and Pacey (2003) find that immigration leads to increases in inequality in Canadian metropolitan areas.

\section{Evidence from the United States}

In the United States scholars have debated the effects of these immigrants on domestic labor market outcomes such as wages, unemployment, and inequality, yet no consensus has been reached in the scholarly literature thus far. In most cases scholars have used micro-level wage data to examine the effects of immigrants on labor market outcomes. They find that immigrants on average have lower levels of earnings than their native-born counterparts. By analyzing Census data over the years, Borjas (1994) finds that the skills of the immigrants entering the U.S. in the post-WWII period declined drastically, and as a result this new immigrant wave earned about $17 \%$ less when they first arrived in the U.S. than native-born Americans. Immigrants also tended to concentrate in low-wage occupations such as construction, seasonal agricultural work, meatpacking, yard service, gardening, and household work (see also Hanson 2004). Borjas has even made a rather bold prediction that it is unlikely that immigrants will catch up economically with their native-born counterparts during their working lives (Borjas 1994: 1713).

Furthermore, the presence of low-skill immigrants increases competition in the lower-wage labor market and alters the supply-demand dynamics of labor. As a result, the influx of low-skill immigrants could depress wages and reduce job opportunities for domestic workers in the low-wage labor market (Borjas 1994, 2004) . For instance, Borjas et al. (1997) estimate that less-skilled immigration accounted for approximately one-third of the decline in the relative wage of high school dropouts in the U.S. between 1980 and 1988. Immigrant workers who came to the United States between 1980 and 2000 reduced the average annual salary of native-born Americans without a high school education by $7.4 \%$ (Borjas, 2004). Using data from the Current Population Survey (CPS) in the 1980s, Topel (2003) also finds that labor markets with the strongest immigrant presence experienced the steepest decline in the wages of native low-skill workers. 
Despite a large amount of empirical evidence supporting the adverse effects of immigration on labor market outcomes for native-born workers, scholars such as David Card argue otherwise. Based on empirical evidence from cross-city comparisons, Card argues in a series of papers that immigrants only have a very small effect (if any at all) on wages and unemployment rates for domestic low-skill workers. Card (1990) conducted a natural experiment based on the 1980 Mariel boatlift delivering 125,000 Cuban immigrants to Miami, Florida. By comparing the wages and unemployment rates in Miami and four other cities (i.e., Tampa, Atlanta, Houston and Los Angeles) before and after the boatlift, he claims that the Cuban immigrants had virtually no effect on wages and unemployment rates in Miami. Instead, the Miami labor market quickly absorbed these Cuban immigrants without affecting native low-skill workers or even other immigrants who arrived to Miami earlier. Further, Card (1990) analyzes U.S. Census data and finds that immigration has no effect on the income growth of the lowest $10^{\text {th }}$ percentile native-born workers in 24 major cities in the United States. Hence he concludes that immigrants did not really depress the income of lower-skill workers. Card and his colleagues later expanded the study to 120 major cities, where they could only find modest competition between immigrants and less-skilled native-born workers-i.e., every $1 \%$ increase in immigration only reduced wages for native low-skilled workers by about $1.2 \%$ (Altonji and Card 1991). Finally, in his most recent work on the subject, Card (2009) claims that immigration has no effect on wage inequality among native-born workers. However, because immigrants themselves are clustered at the high and low ends of the education distribution, they do have a more visible positive effect on wage inequality among all workers.

\section{Additional immigration-based sources of income inequality}

Previous research by economists has focused primarily on immigrants' effect on labor market outcomes such as wages and job opportunities, and their studies have primarily focused on individuals and the aggregate city level. Even though they do not agree on whether or not immigrants negatively affect domestic workers' economic situations, what they do agree on are that (1) the immigrant population is 
bifurcated in terms of labor-market skills, language abilities, education, and income levels, and (2) this bifurcation could contribute to overall income inequality. Yet there is more to the immigration-inequality story. We argue that immigrants face additional constraints in terms of lawful employment practices and eligibility for government-funded welfare programs in the United States, and these constraints further depress the economic status of immigrants in comparison with native-born citizens and hence contribute to higher levels of income inequality.

To a large degree, immigrants—particularly illegal immigrants-face formidable barriers to legal employment in the labor market in comparison with their native-born counterparts. In the face of the current wave of immigration, many states have adopted strict regulations requiring employers to check the legal status of immigrants in the work force. For instance, Arizona, Mississippi, South Carolina, Alabama, Georgia and North Carolina have passed laws that require almost all of their businesses to use the E-verify program to check on employment eligibility for prospective employees, and since the passage of such laws many other states have followed suit. In states where employment eligibility is checked, undocumented immigrants face greater constraints on both their employability and, if employed, their wages, and this could directly result in diminished economic status for immigrants when compared to their native-born counterparts.

Second, for many Americans unearned income derived from public assistance and other benefits received from the federal and state governments is an important supplement for earned income. This income component is especially important for low-income workers because it provides them with a social safety net which could support them during difficult economic times. However, in 1996 the U.S. Congress passed the Personal Responsibility and Work Opportunity Act (PRWORA), which barred immigrants from all federal-funded welfare benefits in the first five years after their arrival. As a result, immigrants are ineligible to receive financial assistance such as Temporary Assistance for Needy Families (TANF) in the first 5 years, although there were exceptions written into the law and states could use state funds to support 
immigrant families. The fact that many immigrants are ineligible to receive federal welfare benefits means that they may not be as financially stable as similarly-situated native-born citizens, and this could result in lower post-redistribution income and, subsequently, higher levels of income inequality.

In this paper we try to put all the pieces together in order to tell a story on how immigration influences inequality. Most of the work examining the linkage between immigration and inequality has focused on individual- and city-level evidence. To fill in the vacuum created by the scarcity of research that has examined the aggregate level relationship between immigration and inequality, we explore how immigration influences income inequality in the American states. We use the American states as our unit of analysis because states vary considerably in their immigration-relevant policies and their socioeconomic and cultural contexts. As a result, each state creates a unique environment within in which immigrants work and live. We posit that for the post-1996 time period there is a positive relationship between immigrants and income inequality in the U.S. for the following reasons: (1) the immigrant population is highly bifurcated in its education, language abilities, job skills, and income; (2) there is a reasonable chance that immigrants have increased competition in the low-wage job market and thus have reduced wages for the low-income group in general; (3) low-skill immigrants-particularly illegal immigrants-face additional constraints than their native counterparts in seeking legal employment; and (4) immigrants are excluded from important components of the American social safety net in at least the first five years after they arrive in the United States.

We also explore the possibility that some immigrants may contribute more to higher income inequality than other immigrants. Specifically, we consider the effects of three specific immigrant groups: (1) newly admitted legal permanent residents, (2) low-skill immigrants, and (3) high-skill immigrants. First of all, new legal permanent residents are granted legal work permits and may have ready access to employment options; subsequently they are likely to face fewer impediments in the labor market than undocumented immigrants. Moreover, many legal permanent residents have lived in the U.S. for a 
sufficiently long time and are hence eligible to receive welfare benefits and participate in other programs in the social safety net if needed. The end result is that new legal permanent residents may not contribute as much to higher income inequality as other types of foreign-born population. Secondly, since our argument about the immigration-inequality linkage centers around the bifurcated skill sets of low-skill and high-skill immigrants, we contend that these two immigrant groups influence levels of income inequality.

\section{DATA AND METHODS}

We explore the effects of immigration on income inequality by using pooled cross-sectional timeseries (CSTS) data from the American states for the years 1996 to 2008 . We connect state-level inequality in (post-transfer) disposable family income with four immigration measures: (1) the overall foreign-born population; (2) the inflow of newly admitted legal permanent residents; (3) low-skill immigrants; and (4) high-skill immigrants. We also include in our model a set of political, economic, and demographic control variables that are suggested in previous scholarly research to influence income inequality.

\section{Dependent Variable}

Income inequality. We use the Gini coefficients for state-level disposable family income inequality as the key measure of our dependent variable. Data on the measure come from Guetzkow, Western, and Rosenfeld (2007) for the 1996-2003 time period, as well as from our update of their data from 2004 to 2008 , generated by using the same procedures. This variable captures post-transfer income inequality, insofar as it is based on an income measure that includes earnings (such as wages and salary) and unearned income (such as government transfers and benefits). Since the economic and policy climate varies substantially across states (within which immigrants can be integrated into the state economy and the state safety-net system), it is appropriate to measure income inequality based on an income variable that includes a wide range of income sources, including both earned income such as wages and salaries and unearned income such as public assistance and benefits. 
Income ratios. As a check on the robustness of our results, we also include data on various income ratios to capture the inequality of incomes for the upper, middle, and lower classes. We focus our attention on standard ratios in the literature that capture the income ratios for upper $\left(90^{\text {th }}\right.$ percentile), middle $\left(50^{\text {th }}\right.$ percentile), and lower $\left(10^{\text {th }}\right.$ percentile) groups, so we begin our robustness check by modeling the $90 / 50,90 / 10$, and 50/10 ratios. We also expand this analysis to include the use of income ratios for the $90^{\text {th }}$ percentile to the $20^{\text {th }}, 30^{\text {th }}$ and $40^{\text {th }}$ percentiles; by doing so we capture income disparities for the upper class and various groups below the middle class.

\section{Immigration Independent Variables}

Foreign-born population. We use the percentage of foreign-born in the total population in each state as our general measure of immigration. This measure not only includes permanent resident immigrants and naturalized citizens, but also temporary legal foreign-born immigrants and undocumented immigrants. ${ }^{1}$ Data on the foreign-born population are collected from Current Population Surveys dating from 1996 to 2008. Regrettably, data at the state level on foreign-born population prior to 1996 are available only during Census years, so we are unable to extend our yearly analysis to earlier years. We hypothesize that the coefficient for this variable will be positive, indicating that income inequality increases with higher levels of foreign-born population.

Newly admitted Legal Permanent Residents (LPRs). We use the percentage of newly admitted LPRs in the total population in each state as a measure for the inflow of permanent residents. According to our theoretical arguments, we expect that newly admitted LPRs will have an effect on income inequality that is indistinguishable from the effect of the general foreign-born population.

Low-Skill and High-Skill Immigration. Americans are divided in how they think about high- and low-skill immigrants, particularly in terms of their perceptions of the economic benefits and costs of these two

\footnotetext{
${ }^{1}$ While the CPS does include illegal immigrants in its sample, it does so without including sufficient information to identify illegal immigrants explicitly. It is also the case that the undocumented immigration population is likely underrepresented in the CPS - a typical feature of similar national household surveys.
} 
immigrant groups (Hainmueller and Hiscox, 2010; Malhotra, Margolit, and Mo, 2013). We further disaggregate states' foreign-born population by skill levels to calibrate the size of the low-skill and high-skill immigration subpopulations. Education attainment is a partial--albeit useful-proxy for skill levels. Using the Census Bureau's Current Population Surveys Annual Social Economic Supplements, we measure the low-skill immigration variable as the percentage of immigrants who do not have a high-school diploma, while we measure the high-skill immigration variable as the percentage of immigrants who have earned a college degree or above. By disaggregating the total foreign-born population by skill levels we are able to unpack how these two subpopulation groups are linked to income inequality.

\section{Political contextual independent variables}

Since Bartels' (2008) work exploring the effect of presidential partisanship on income inequality in the U.S., scholars have documented the negative effect of conservative power in the federal/state government on income inequality (Kelly and Witko 2012). This reflects arguments from the comparative political economy literature suggesting that organizational power of the poor and working classes-such as leftwing parties and labor unions-is more likely to favor the interests of the working class, resulting in lower income inequality. On the other hand, organizational power of the middle and upper classes (such as right-wing parties) is more likely to support the interests of their middle- and high-income constituents, resulting in higher income inequality (Tufte 1980; Bradley et al., 2005; Korpi and Palme 2003). Following this argument we include a full set of political variables as explanations for state-level income inequality.

State government liberalism. We consider state government liberalism as a possible explanation for income inequality. We use the state government liberalism indicator created by Berry, Ringquist, Fording and Hanson (1998), which measures the ideological orientation of each state government. This variable is measured on a scale that ranges from 0 to 100, with 0 meaning extremely conservative public ideology and 100 meaning extremely liberal ideology. This measure accounts for "the most important complexities 
of applying the idea of political power resources to the context of the American states" (Kelly and Witko, 2012: 418). We hypothesize that state government liberalism has a negative effect on income inequality.

Union density. Union density measures the percentage of nonagricultural wage and salary employees (including public-sector employees) who are union members. Data on union density are compiled by Hirsch (2012) , who collects state-level union density from 1964 to 2012 using a combination of Bureau of Labor Statistics (BLS) and the Current Population Survey (CPS) data. This measure varies from a low of 2.3\% to $38.7 \%$, with a higher value indicating a stronger labor union presence in the state. We hypothesize that the coefficient for this variable will be negative, indicating that higher state labor union density depresses income inequality at the state level.

Federal government partisan control. According to Kelly and Witko (2012), partisan control of both federal- and state-level governments can have distributive consequences and can hence affect state-level income inequality. Bartels (2008) has also shown evidence that the partisanship of the president affects income inequality at the national level. We build on this argument and suggest that Republican-controlled federal government has a positive effect on state-level income inequality, independent of the effect of state government ideology. We code this variable as the number of the three political institutions-the presidency, the U.S. House, and the U.S. Senate-controlled by the Democratic Party. This variable is coded 0 for Republican control of the federal government, and 3 for Democratic control.

\section{Social and Demographic Control Variables}

Real GDP per capita growth. The role of economic development and economic growth in shaping levels of income inequality has long been the subject of scholarly inquiry (Kuznets, 1953, 1955), and there is some debate about the relationship between economic growth and income inequality (Bartels, 2009). In recent years many observers have expressed concerns that the current trends in income inequality in the United States are due to a pattern of high economic growth that is spread unevenly throughout the income distribution (Bartels 2008). If economic growth is distributed in such a way that most of the gains 
are received by those in the higher income strata, then economic growth would be positively related to state income inequality. We use real per capita income growth rate as a measure of economic growth, and we posit that this variable will have a positive effect on income inequality.

Manufacturing. Scholars have pointed out that the manufacturing sector represents the largest share of the labor market and is characterized by high productivity and relatively high unionization. In developed countries, labor shifting from smaller sectors with lower productivity (e.g., agriculture) to manufacturing has the effect of decreasing income inequality (Benard and Jensen, 1998; Grant and Wallace, 1994; Rodwin and Sazanami, 1991). Using county-level data in the United States, Nielsen and Alderson (1997) find that manufacturing employment has a negative effect on income inequality. To capture sector effects, we include as a control variable the proportion of manufacturing as a share of gross state product. We expect that the size of the manufacturing sector has a negative effect on income inequality.

College graduates. Crenshaw and Ameen (1994), Jacobs (1998), and Nielsen and Alderson (1997) find that education levels of the population influence income inequality, with both high and low levels of education leading to higher inequality. Due to technological advancement over the past 40 years, highlyeducated people have witnessed a significant increase in their earnings, but people with only a high school education or those who fail to complete high school have seen a steady decline in their incomes (Bartels, 2008; Dooley and Gottschalk, 1985; Gottschalk, 1997). Goldin and Katz (2008) suggest that rising income inequality is a result of an American educational system that has not kept up with the technological revolution over the past three decades. They argue that income inequality has increased because the demand for high-skill workers has risen faster than its supply but lower-skill workers have failed to keep up with the technological requirements of the present-day economy. Given the importance of education in shaping levels of income inequality, we include in our models the percentage of college graduates as a share of state population. We expect this variable to have a positive effect on income inequality. 
Nonwhite Population. The existing literature suggests that the size of ethnic minority population matters for income inequality, but there are competing expectations about the direction of this effect. On one hand, Latinos and African Americans are the largest minority groups, representing almost $80 \%$ of the non-white population. The income gaps between white and minority households-particularly for black and Latino households-has been well documented (Nielsen and Alderson, 1997; DeNavas-Walt and Proctor 2014). Since members of minority groups have lower mean income than whites, an increase in the minority population should be associated with greater dispersion in overall state incomes. Indeed, Kelly and Witko (2012) find that income inequality is higher in states with larger nonwhite populations. On the other hand, the U.S. immigrant population is ethnically diverse, with migration from Latin America and Asia largely driving the recent wave of immigration. Preuhs (2007) and Fording (1997) find that the presence of minority population in general can affect policies affecting minority groups, particularly if the minority population is accompanied by high mobilization and/or incorporation through descriptive representation in policy-making bodies. Given this, we include the percentage of the nonwhite population as a control variable to capture the effect of ethnic minority population on income inequality. If the thesis of racial disparity in income holds, we would expect a positive association between nonwhite population and income inequality. If the mobilization/incorporation thesis is true, we would expect to observe a negative association between nonwhite population and income inequality. ${ }^{2}$

Unemployment. Thurow (1987) predicts a positive relationship between the unemployment rate and income inequality, since a high unemployment rate creates more people at the lower ends of the income

\footnotetext{
${ }^{2}$ We also estimate our models using different configurations of racial and ethnic population groupings. When we estimate our models by replacing the nonwhite population percentage with the black population percentage, our findings remain the same. On the other hand, when we include both the black population percentage and the Latino population percentage in our model, multicollinearity becomes an issue since a large proportion of the immigrant population is also Latino. Given this, we follow the practice of Kelly and Witko (2012) and include the nonwhite population percentage as the best measure to capture the effects of minority population in income inequality in the American states.
} 
distribution. We include the state unemployment rate as a control variable and expect that the coefficient for this variable will be positive, indicating that unemployment has a positive effect on inequality.

Female labor force participation. Conventional wisdom suggests that more women joining the workforce could lead to widening family income gaps, since high-income, high-education women tend to marry high-income men. However, Nielsen and Alderson (1997) and Treas (1987) show that female labor force participation-especially the participation of low-income women-has an equalizing effect on family incomes. Considering these arguments, we control for female labor force participation in our analyses and hypothesize that this variable will be negatively related to income inequality.

\section{Methods}

In order to estimate the effect of immigration on income inequality in the United States-all-the-while controlling for the effects of the prevailing federal /state political environment-we use multiple estimation procedures. First, we use static Ordinary Least Square (OLS) models as a baseline specification to estimate the effects of immigration (i.e., foreign-born population, LPRs, low-skill and high-skill immigrants) on income inequality. Second, we estimate dynamic models of income inequality using the Error-Correction Model (ECM), in which we estimate the first-order change in income inequality as a function of the lagged-level of income inequality, a lagged term and a first-order difference term of each of the four immigration variables, as well as a battery of control variables (De Boef, 2001; De Boef and Keele, 2008). We suggest that the $E C M$ is a proper dynamic model specification because it helps minimize the potential of spurious regressions with the presence of non-stationary time-series data (De Boef and Granato, 1997). Panel unit root tests of our inequality measures find consistent evidence that they are non-stationary, meaning that the structure of inequality has a long-term memory. Prior studies also suggest that there are dynamic relationships between state-level income inequality and various socioeconomic and political variables (Kelly and Witko 2012). This model specification can capture both the short-term and long-term effects of immigration on income inequality. However, we also present 
results of basic static models due to the short time dimension of our CSTS data and for the sake of comparison. In both the OLS model and the ECM, we also consider the possibility that there is a spatial pattern regarding how the foreign-born population is spread across the 50 states. Hence, we apply panelcorrected standard errors (PCSEs) to correct for spatial autocorrelation.

\section{EMPIRICAL RESULTS}

\section{The Effects of Foreign-Born Population and the LPRs}

We begin by using data from the CPS March Survey to calculate U.S. national level income inequality levels from 1996 to 2008 with and without the immigrant population. In Figure 1 we present a comparison of these two trends. As one can see, the level of income inequality is always higher when we include immigrants in the population. This figure shows that income inequality in the U.S. over the past two decades is indeed marginally higher due to immigration. To be sure, the gap in income inequality with and without immigrants is modest, but there is at least a small upward shift when immigrants are included in the population used to calculate income inequality.

What is the effect of immigration on income inequality, controlling for the effects of federal/state political context and other independent variables? In order to explore this question, we estimate both static OLS (Table 1) and dynamic ECM (Table 2) models to show how immigration affects income inequality, as well as the degree to which certain types of immigrants significantly contribute to rising of income inequality. ${ }^{3}$

We focus our attention first on the first two measures of immigration in both the static and dynamic models. In Table 1 we present the static multivariate cross-sectional time-series estimates for three

\footnotetext{
${ }^{3}$ At a simple level, we can see that immigration and income inequality are correlated over the time period of our study. In Appendix Figure A1, we present the trends in the average Gini coefficient of income inequality and average size of foreign-born population from 1996 to 2008. As one can see, the trends in the yearly means for immigration and income inequality are strongly and positively correlated with each other $(r=0.723)$. We also estimate correlations in trends for immigration and income inequality separately for each state. Because of the small sample sizes for each state the levels of statistical significance are attenuated, but we find that 41 of 50 correlations are positive, and of these 20 are significant at least at the somewhat relaxed 10 level. Further, 39 of the 50 states exhibit a significant upward trend for both the Gini coefficient and foreign-born population variables.
} 
models. The first model only includes the foreign-born population as the measure of the immigrant population, while the second model only includes the immigration variable for newly admitted LPRs. The third model is a full model that includes both of these immigration variables. As one can see, the foreignborn population variable has a significant and positive effect on the level of income-inequality in both Model (1) $(b=0.001, z=5.89)$ and Model $(3)(b=0.001, z=3.24)$. Simply, as the foreign born population increases, the level of post-redistribution income inequality also increases, controlling for the effects of the political contextual variables and other independent variables. In addition, the effects of newly-admitted LPRs is also positive and highly significant $(b=0.028, z=4.95)$ in Model $(2)$, which is estimated without the foreign-born population variable.

When we include both the foreign-born population and the newly-admitted LPRs variables in the same model, the effect of the former on income inequality remains strong, but the effect of the latter disappears to statistical nonsignificance. We note that the coefficients for the newly-admitted LPR variable must be interpreted with care. Because newly admitted LPRs are encompassed within the foreign-born population variable, the coefficient for the newly admitted LPRs represents the difference in the effects of LPRs and the effect of the non-LPR foreign-born population. (In Appendix 1 we present a brief discussion of this point.) The question is whether or not new LPRs have an additional effect on income inequality above and beyond the effect of the general foreign-born population. However, as one can see from Table 1, we find that newly-admitted LPRs do not have a significant effect above and beyond that of the general foreignborn population $(b=0.002, z=0.19)$. Our results suggest that it is the general foreign-born population that increases income inequality in the American states and that newly-admitted are statistically indistinguishable in their effect on state income inequality.

In Table 2, we present the coefficients for our dynamic models of state-level income inequality. Once again, we find that income inequality increases in states with a larger foreign-born population. Model (1) in Table 2 is estimated by only including the foreign-born population variable as our immigration measure. 
This model shows that the lagged Gini coefficient is negatively associated with the change in state-level income inequality $(b=-0.717, z=-8.06)$, meaning that the level of income inequality at time $t$ is negatively correlated with the level of income inequality in the previous time period, $\mathrm{t}-1$. In other words, in the long term income inequality would revert toward the underlying equilibrium level--an increase (decrease) in the level of income inequality in the previous year ( $t-1$ ) leads to a significant decrease (increase) in income inequality in the subsequent year. Turning to the immigration variable in Model (1) of Table 2, we see that the lagged foreign-born population variable has a positive and significant effect on change in income inequality $(b=0.001, z=3.48)$. This coefficient represents a positive long-term effect on income inequality associated with a one-unit increase in immigration in the previous year ( $\mathrm{t}-1)$. This long-term effect will be distributed over future time periods according to the rate of error correction (i.e. the coefficient of the lagged dependent variable). The error correction model specifies a long-run equilibrium relationship between immigration and inequality. An increase in immigration at year $t$ disrupts the underlying equilibrium, causing inequality to increase a total of 0.0014 points, spreading over subsequent years at a rate of $71.7 \%$ per year. Specifically, the long-term effect of immigration on inequality is captured by the coefficients of the lagged Gini coefficient $(b=-0.717, z=-8.06)$ and lagged foreign-born population $(b=$ $0.001, z=3.48)$. Using DeBoef and Keele's (2008) approach for measuring long-term effects, we approximate the total long-term effect as equal to $0.0014 .{ }^{4}$ The bottom line is that the foreign-born population appears to have a strong positive long-term effect on income inequality in the American states. These results provide strong support for our hypothesis that immigration is associated with higher levels of income inequality.

In Model (2) and (3) of Table 2 we further explore the degree to which income inequality in the American states is affected-at least in part-by newly admitted legal permanent residents. As is the case for Model (2) in Table 1, we find some evidence that income inequality is related positively to the inflow of

\footnotetext{
${ }^{4}$ Following DeBoef and Keele (2008: 193), we can calculate the long-term effect of immigration as follows: Long term effect $=(0.001) /-[-0.717])=0.0014$.
} 
newly admitted LPRs $(b=0.018, z=2.87)$. Model (3) leads to the same substantive conclusion as Model (1) regarding the short-term and long-term effects of foreign-born population on the change in income inequality-i.e., that foreign-born population has a significant and positive long-term effect on inequality. Yet our findings suggest that newly admitted LPRs do not have an effect on income inequality above and beyond the effect of the general foreign-born population $(b=0.000, z=0.09)$. We contend that it is the foreign-born population in general that contributes to income inequality, with newly admitted LPRs contributing no additional independent effect on income inequality in the American states.

A quick review of the control variables in Table 2 shows that the coefficients are generally consistent with our expectations. First, both the level of union density and the change in union density are negatively associated with the change in income inequality; simply, union membership has the effect of depressing levels of income inequality, which confirms our theoretical assumption. On the other hand, increased state government liberalism does not, as expected, lead to a decrease in income inequality; this indicates that left political power in state governments does not depress income inequality, at least during the time period under study. Turning to the socioeconomic variables, there is a positive relationship between real per capita income and income inequality; this suggests that the level of income inequality is higher in richer states than in poorer states. Moreover (and as expected), both higher percentages of college graduates and high unemployment rates are positively related with the change in income inequality, while female labor participation is negatively associated with the change in income inequality. Finally, the lagged level of non-white population is positively associated with the change in income inequality. This finding is indicative that in states with large minority populations, there are also salient racial disparities in income.

\section{The Effects of Low- and High-Skill Immigrants}

Thus far we have explored the effects of the general foreign-born population on income inequality, as well as the degree to which newly-admitted LPRs have an additional effect above and beyond the effect of foreign-born population. Our findings point to a general effect of the foreign-born population, with the 
effect of newly-admitted LPRs of a similar magnitude to that of the foreign-born population. However, it is possible that there are other sources of heterogeneity in the effect of immigration on income inequality. One possibility is that the effect of immigration effect varies with the skill levels of the foreign-born population. On one hand, it is possible that low-skill immigrants have an effect beyond that of the general foreign-born population, since low-skill immigrants are most likely to be in the low-wage labor market, experience unstable employment opportunities, and have reduced access to various programs that are part of the social safety net. It is also at least theoretically possible that high-skill immigrants also have an effect on income inequality, since their incomes may be higher than the median and may stretch the income distribution in an upward direction. To capture these possible effects, we replace our general foreign-born population variable with variables representing the share of low-skill immigrants (i.e., those with educational attainment less than a high-school education) and the share of high-skill immigrants (i.e., those with a college degree).

Turning to Table 3, in Model (1) we report the results of a model in which state income is depicted as a function of the low- and high-skill immigration variables as well as political and social demographic control variables. As one can see, without controlling for other immigration variables, the lag term of low-skill immigration has a significant and positive effect on income inequality $(b=0.001, z=3.98)$. When we only include the measure for high-skill immigration in Model (2), we also find that the lagged term of high-skill immigration has a significant positive association with income inequality $(b=0.001, z=1.70)$. Turning to Model (3) in Table 3, we include both low- and high-skill immigration in the model. We find that only the lagged term of low-skill immigration has a significant and positive effect on income inequality $(b=0.001$, $z=3.53)$. Our empirical findings in Table 3 suggest that the positive effect of immigration on income inequality is primarily driven by low-skill immigration.

The conclusion that we can draw from Tables 1-3 is that immigration has a positive and significant long-term effect on state-level income inequality. The general foreign-born population has a strong, 
consistent effect on inequality, though there is little evidence that newly admitted LPRs have an additional effect that goes beyond that of the general foreign-born population. Our evidence also shows that it is low-skill immigrants that have a sizable positive effect on income inequality. Overall, at this point we see a strong positive effect of the general foreign-born population as well as low-skill immigrants on income inequality. In state-year observations with relatively large immigrant populations or low-skill immigrant population, income inequality is higher, controlling for the effects of political and social demographic control variables.

\section{Robustness tests using income ratios}

In order to check the robustness of our findings, we re-estimate our models using alternative measures of income inequality based on various income ratios; these results are reported in Appendix Tables A1-A2 in our supporting documentation. As a starting point we use the $90 / 10,50 / 10$ and $90 / 50$ income ratios as our dependent variables, and in Table A1 we find that foreign-born population has a strong effect on the $90 / 10$ and $90 / 50$ income ratios but not on the $50 / 10$ income ratio. These results suggest that the foreign-born population depresses incomes of those at the middle and lower ends of the income distribution relative to incomes at the high end of the income distribution. It is perhaps a bit puzzling that the positive effect of the foreign-born population on the 50/10 income ratio does not achieve statistical significance. In one sense, we would expect the coefficient for the foreign-born population to have a strong positive effect on the 50/10 ratio under the argument that those in the lowest-wage labor market are most likely to be affected by the influx of immigrants, while individuals with incomes that plant them firmly in the middle class would be less affected by the foreign-born population. As is, our findings suggest that immigration has little effect on the income gap between the median income group and the middle-to-lower classes.

Following up on our findings from Table A1, we also consider in Table A2 the degree to which the $90 / 10,90 / 20,90 / 30$, and $90 / 40$ ratios are affected by the foreign-born population, and we find strong 
evidence of immigration effects in all four models. Overall, it appears that immigration has an effect on the income ratios comparing upper income groups with those with lower and middle-to-lower incomes, and these results are consistent with the general finding that the foreign-born population in the American states has an effect on income inequality.

In Tables A3-4 we replicate the analysis in Table A1-A2, but for these models we replace the overall immigration measure with our measures of low- and high- skill immigration. Consistent with our main results reported in Table 3, we find that it is low-skill immigration that significantly affects various income ratios and hence increases income inequality. Controlling for the effects of other independent variables, we find that low-skill immigration has a positive and significant association with the $90 / 10$ and $90 / 50$ income ratios, but not the 50/10 income ratio; this suggests that low-skill immigrants lead to higher levels of income inequality between those at the upper end of the income distribution, on one hand, and those with lower and middle incomes. However, it is worth noting as well that high-skill immigration lowers income inequality for the $90 / 50$ income ratio in both the long and short run; this suggests that high-skill immigrants raise median incomes relative to those at the highest end, with the result being significantly lower levels of income inequality. We follow up this analysis with the model estimates reported in Table A4, in which we replicate the results from Table A2 but with the low-skill and high-skill immigration variables substituting for the general foreign-born population variable. Consistent with the results from Table A2, in Table A4 we show that low-skill immigration has a significant and positive impact on 90/10, $90 / 20,90 / 30$, and $90 / 40$ income ratios, suggesting that income inequality between high- and lowerincome groups expands as a function of increases in the low-skill immigration population. Our results from Table A4 also reveal that high-skill immigrants have significant negative effects on income inequality as measured by the $90 / 20,90 / 30$, and $90 / 40$ ratios. This provides strong evidence of the different effects of low-and high-skill immigrants on inequality across various parts of the income distribution. Presumably, high-skill immigrants lift up incomes for those in all but the very poorest income decile relative to those in 
the highest income decile. Taken as a whole, these results confirm that the low-skill immigration depresses incomes of those at the middle and lower ends of the income distribution relative to incomes of those at the high end of the income distribution. However, we also find that high-skill immigrants may have an effect on lowering income inequality for some segments of the income distribution. These findings verify our argument that the immigrant population in the U.S. is bifurcated in its skill sets, which is an important driving force for income inequality.

\section{CONCLUSION}

In this paper we contribute to the existing literature on income inequality in the American states by exploring the explanatory value of immigration while at the same time considering federal and state political and socioeconomic contexts. Simply, we suggest that there is a positive long-term effect of immigration on income inequality in the American states. Immigrants are bifurcated in their skill sets, marketability, and income levels. They might possibly take away job opportunities from native-born workers and depress their wages, yet immigrants also face barriers in seeking legal employment and their ability to participate in welfare programs. All of these conditions contribute to a positive general effect of immigration on income inequality. Moreover, we consider the degree to which three subsets of immigrants—newly admitted legal permanent residents, low-skill immigrants and high-skill immigrants— have effects on income inequality.

In order to estimate the effects of immigration on income inequality, we begin by using national income data to calculate Gini coefficients separately for income distributions that include and exclude the foreign-born population. We find that inequality levels have been consistently (but only modestly) higher for the income distribution with immigrants than inequality levels for the income distribution without immigrants. Further, in order to estimate the degree to which immigrants promote income inequality, we employ both static and dynamic models of income inequality in the American states from 1996-2008. We find strong and consistent evidence that the foreign-born population has significant and positive long-term 
effects on state-level income inequality. The finding of such strong effects is reinforced in robustness tests that are based on income ratios between those at the high end of the income distribution and those at the medium and low levels (i.e., the 90/10, 90/20, 90/30, 90/40 and 90/50 income ratios). Simply, the foreignborn population is positively and significantly related to higher income ratios for these income pairings.

In addition, we find that newly admitted LPRs do not have any significant effect on state-level income inequality above and beyond the effect of the general foreign-born population. Yet, our additional models with data measuring low- and high-skill immigration show some important differences in how these immigrant groups affect income inequality. We find a significant and positive effect of low-skill immigration on income inequality, both in general (as measured by the Gini coefficient) and for specific income ratios comparing high-income individuals with those at the median income and below. Simply, low-skill immigrants have the effect of increasing income inequality in the American states. On the other hand, while high-skill immigrants do not have an effect on income inequality as measured by a general indicator such as the Gini coefficient, high-skill immigrants do depress income inequality for certain segments of the income distribution-most notably, in comparisons between those in the top income decile and those at the median income or below.

Several independent variables are found to have significant effects on income inequality. We find that union density has a negative effect on state income inequality, though state government liberalism and Democratic control of national government have little effect on the dependent variable. Five of the social demographic control variables significantly influence state income inequality. While female labor force participation has a negative effect on inequality, the unemployment rate, percent of college graduates, nonwhite population, and (to a lesser extent) real per capita income all promote higher levels of income inequality. States with lower female labor force participation rates, high unemployment, a large minority population, an educated citizenry with a large share of college graduates, and high rates of economic growth are particularly likely to have a higher level of income inequality. 
Taken as a whole, our empirical results provide macro-level support for previous findings documented by economists that immigration increases wage inequalities at the micro-level (Borjas, 1994, 2000, 2004; Chevan and Stokes, 2000; Reed, 2001). Most importantly, the effect of immigration on inequality is consistent and robust when we control a full set of political and social demographic control variables or when we use alternative inequality measures.

What are the political and policy implications of our findings? First, we contend that immigration has had-and will continue to have-an important effect on domestic economic outcomes. In particular, our findings suggest that immigration contributes to the increasing economic disparity among members of society. This is a non- trivial effect of immigration and is a result of relative disadvantages that immigrants have in marketable skills, but also due to laws, politics, and policies. State policies that create and maintain a strong social safety net for the foreign-born population may generate a weaker effect of immigration on inequality, since immigrants in the low-wage labor market may be more likely to benefit from such redistributive policies. The adoption of a wider-range of social safety net policies benefitting immigrants may help to close the income gap between immigrants and their native-born counterparts and hence result in a reduced effect of immigration on state income inequality.

Alternatively, it is clear from our findings that the mix of immigrants who come to the United States influence the levels of income inequality in the American states. Our findings that low-skill immigrants raise income inequality while high-skill immigrants lower income inequality for certain selective income pairings point to the importance of considering the values that undergird American immigration policy. One possible way to mitigate the effects of immigration on income inequality is to see changes in immigration policy that result in a change in the mix of immigrants admitted to the United States. An immigration policy that shifts the focus toward admitting more high-skill immigrants and fewer low-skill immigrants may reduce the effect of immigration on income inequality. 
Figure 1: Gini coefficients with and without immigrants in the United States

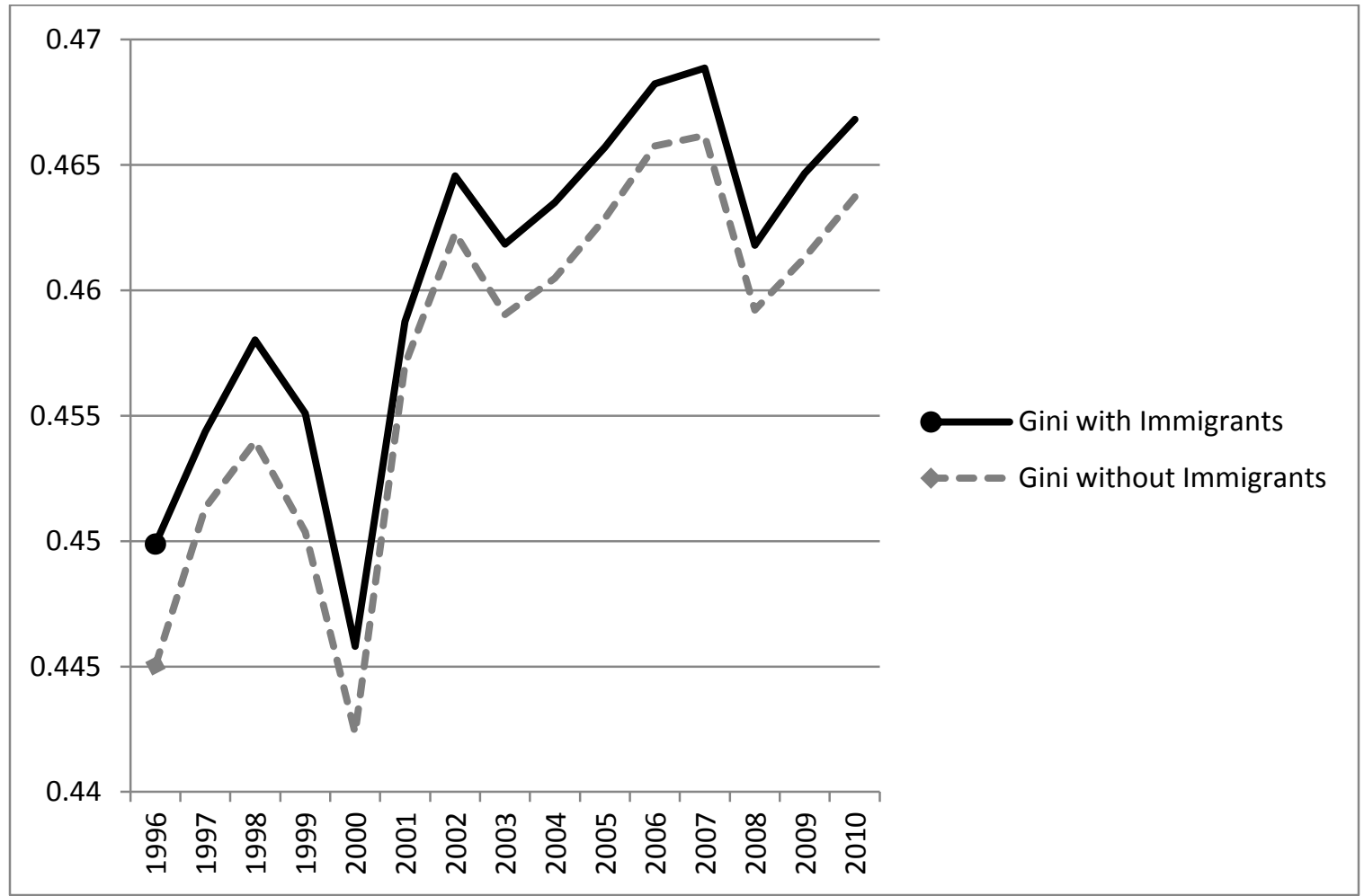


Table 1. Panel corrected standard error (PCSE) estimates of effect of immigration on state income inequality, static estimates, 1996-2008

\begin{tabular}{|c|c|c|c|c|c|c|}
\hline \multirow[b]{2}{*}{ Variable } & \multicolumn{2}{|c|}{ (1) } & \multicolumn{2}{|c|}{ (2) } & \multicolumn{2}{|c|}{ (3) } \\
\hline & $\mathrm{b}$ & $\mathrm{z}$ & $\mathrm{b}$ & $\mathrm{z}$ & $\mathrm{b}$ & z \\
\hline Foreign-born population & 0.001 & $5.89 * * *$ & --- & --- & 0.001 & $3.24 * * *$ \\
\hline Newly-admitted legal permanent residents & --- & --- & 0.026 & $4.95^{* * *}$ & 0.002 & 0.19 \\
\hline Union density & -0.001 & $-6.68 * * *$ & -0.001 & $-7.31 * * *$ & -0.001 & $-7.49 * * *$ \\
\hline State government liberalism & 0.000 & -0.68 & 0.000 & -1.08 & 0.000 & -0.74 \\
\hline Real per capita income growth & 0.000 & 0.79 & 0.000 & 0.73 & 0.000 & 1.11 \\
\hline Manufacturing & -0.002 & -0.15 & 0.000 & 0.01 & 0.003 & 0.26 \\
\hline College graduates & 0.071 & $3.21 * * *$ & 0.083 & $3.92 * * *$ & 0.074 & $3.26 * * *$ \\
\hline Nonwhite population & 0.021 & $3.85^{* * *}$ & 0.028 & $5.11 * * *$ & 0.021 & $3.74 * * *$ \\
\hline Unemployment rate & 0.002 & $3.08 * * *$ & 0.002 & $3.42 * * *$ & 0.002 & $3.17^{* * *}$ \\
\hline Female labor force participation & -0.001 & $-4.24 * * *$ & -0.001 & $-5.84 * * *$ & -0.001 & $-5.26 * * *$ \\
\hline Federal government partisan control & -0.003 & -1.60 & -0.003 & $-1.97 *$ & -0.003 & $-1.90 *$ \\
\hline Constant & 0.444 & $31.76 * * *$ & 0.450 & $33.62 * * *$ & 0.444 & $32.54 * * *$ \\
\hline $\mathrm{N}$ & \multicolumn{2}{|c|}{650} & \multicolumn{2}{|c|}{637} & \multicolumn{2}{|c|}{637} \\
\hline $\mathrm{R}^{2}$ & \multicolumn{2}{|c|}{0.341} & \multicolumn{2}{|c|}{0.356} & \multicolumn{2}{|c|}{0.364} \\
\hline Wald $\chi^{2}$ & \multicolumn{2}{|c|}{675.48} & \multicolumn{2}{|c|}{715.61} & \multicolumn{2}{|c|}{664.78} \\
\hline Prob (Wald $\chi^{2}$ ) & \multicolumn{2}{|c|}{0.000} & \multicolumn{2}{|c|}{0.000} & \multicolumn{2}{|c|}{0.000} \\
\hline
\end{tabular}

$* * *$ prob $<0.001 \quad * *$ prob $<0.01 \quad * \quad$ prob $<0.05$ 
Table 2. Panel corrected standard error (PCSE) estimates of effect of immigration on change in state income inequality, dynamic estimates, 19962008

\begin{tabular}{|c|c|c|c|c|c|c|}
\hline \multirow[b]{2}{*}{ Variable } & \multicolumn{2}{|c|}{ (1) } & \multicolumn{2}{|c|}{ (2) } & \multicolumn{2}{|c|}{ (3) } \\
\hline & b & $z$ & b & $\mathrm{z}$ & $b$ & $\mathrm{z}$ \\
\hline Lagged Gini coefficient- & 0.717 & $-8.06 * * *$ & -0.699 & $-8.03 * * *$ & -0.710 & $-8.09 * * *$ \\
\hline Lagged foreign-born population & 0.001 & $3.48^{* * *}$ & --- & --- & 0.001 & $1.94^{*}$ \\
\hline First difference, foreign-born population & 0.000 & 0.37 & --- & --- & 0.000 & 0.09 \\
\hline Newly-admitted legal permanent residents & --- & --- & 0.018 & $2.87^{* *}$ & 0.001 & 0.09 \\
\hline Lagged union density & -0.001 & $-4.00 * * *$ & -0.001 & $-3.62 * * *$ & -0.001 & $-3.71 * * *$ \\
\hline First difference, union density & -0.001 & $-1.76^{*}$ & -0.001 & -1.58 & -0.001 & $-1.65^{*}$ \\
\hline Lagged state government liberalism & 0.000 & 0.11 & 0.000 & 0.02 & 0.000 & 0.30 \\
\hline First difference, state government liberalism & 0.000 & -1.46 & 0.000 & -1.49 & 0.000 & -1.40 \\
\hline Lagged real per capita income & 0.000 & -0.41 & 0.000 & -0.67 & 0.000 & -0.33 \\
\hline First difference, real per capita income & 0.002 & $1.75^{*}$ & 0.002 & 1.54 & 0.002 & $1.65^{*}$ \\
\hline Lagged manufacturing & -0.003 & -0.22 & -0.002 & -0.12 & -0.001 & -0.04 \\
\hline First difference, manufacturing & 0.059 & 0.86 & 0.055 & 0.80 & 0.048 & 0.69 \\
\hline Lagged college graduates & 0.045 & $1.87^{*}$ & 0.054 & $2.47^{* *}$ & 0.047 & $2.18^{*}$ \\
\hline First difference, college graduates & 0.117 & $2.16^{*}$ & 0.117 & $2.10^{*}$ & 0.112 & $2.02^{*}$ \\
\hline
\end{tabular}


Table 2 (continued)

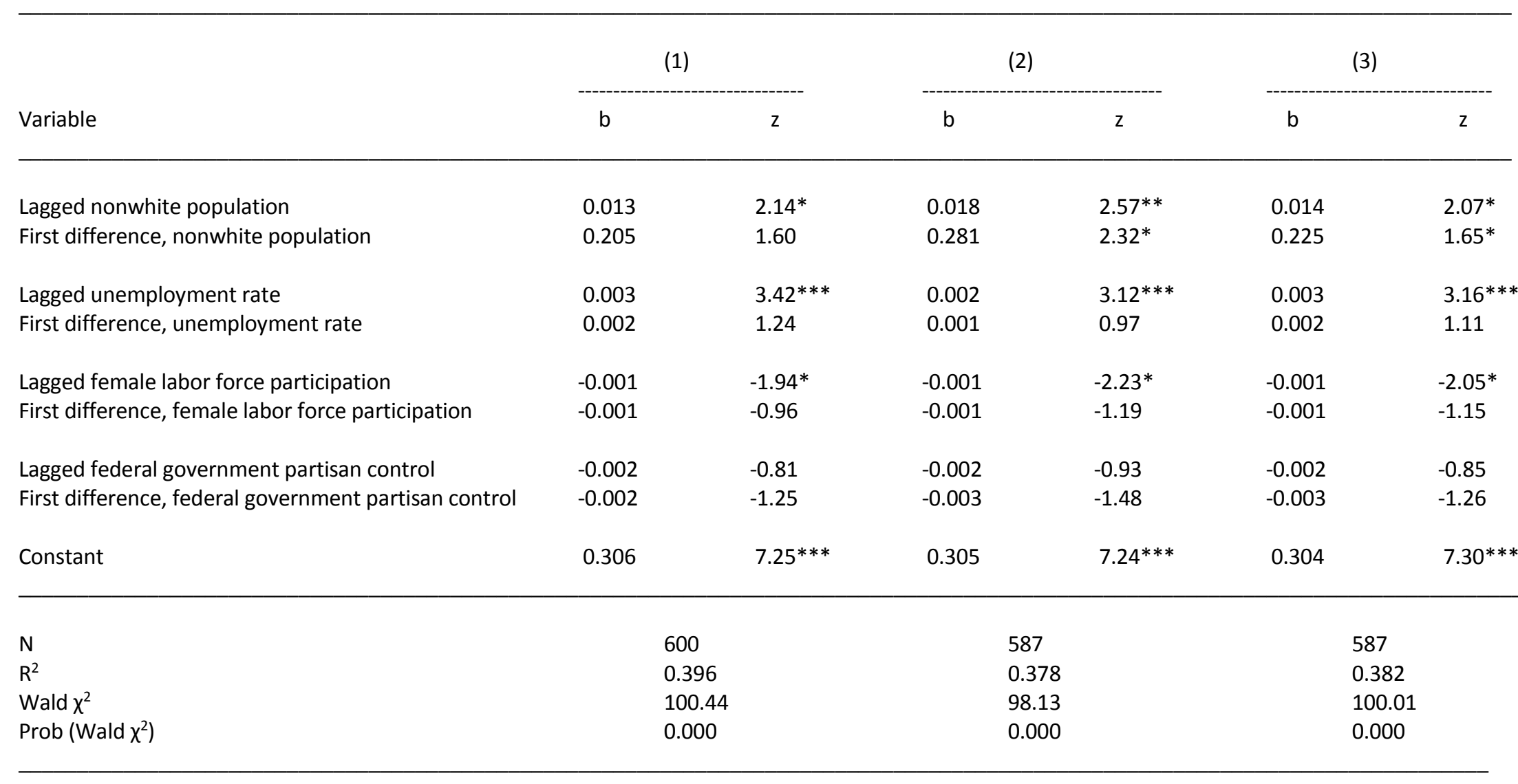

$* * *$ prob $<0.001 * *$ prob $<0.01 \quad * \quad$ prob $<0.05$ 
Table 3. Panel corrected standard error (PCSE) estimates of effect of high- and low-skill immigrants on state income inequality, dynamic estimates, 1996-2008

(1)

\begin{tabular}{|c|c|c|c|c|c|c|}
\hline \multirow[b]{2}{*}{ Variable } & & & \\
\hline & $\mathrm{b}$ & z & $\mathrm{b}$ & z & $\mathrm{b}$ & z \\
\hline Lagged Gini coefficient & -0.725 & $-8.12 * * *$ & -0.696 & -7.86 & -0.726 & $-8.12 * * *$ \\
\hline Lagged low-skill foreign-born population & 0.001 & $3.98 * * *$ & --- & --- & 0.001 & $3.53 * * *$ \\
\hline First difference, low-skill foreign-born population & 0.001 & 0.46 & --- & --- & 0.001 & 0.65 \\
\hline Lagged high-skill foreign-born population & --- & --- & 0.001 & $1.70^{*}$ & -0.001 & -0.50 \\
\hline First difference, high-skill foreign-born population & --- & --- & 0.002 & 1.03 & 0.001 & 0.43 \\
\hline Lagged union density & -0.001 & $-3.72 * * *$ & -0.001 & $-3.38 * * *$ & 0.000 & $-2.94 * *$ \\
\hline First difference, union density & -0.001 & $-1.69 *$ & -0.001 & -1.61 & -0.001 & $-1.65^{*}$ \\
\hline Lagged state government liberalism & 0.000 & 0.18 & 0.000 & -0.37 & 0.000 & 0.16 \\
\hline First difference, state government liberalism & 0.000 & -1.55 & 0.000 & -1.51 & 0.000 & -1.58 \\
\hline Lagged real per capita income & 0.000 & -0.05 & 0.000 & -0.63 & 0.000 & 0.08 \\
\hline First difference, real per capita income & 0.002 & $1.80^{*}$ & 0.002 & 1.55 & 0.002 & $1.79 *$ \\
\hline Lagged manufacturing & -0.007 & -0.45 & -0.011 & -0.74 & -0.007 & -0.45 \\
\hline First difference, manufacturing & 0.060 & 0.87 & 0.060 & 0.87 & 0.064 & 0.95 \\
\hline Lagged college graduates & 0.057 & $2.58^{* *}$ & 0.048 & $1.75^{*}$ & 0.064 & $2.25^{*}$ \\
\hline First difference, college graduates & 0.123 & $2.32 * *$ & 0.114 & $1.97^{*}$ & 0.121 & $2.16^{*}$ \\
\hline
\end{tabular}


Table 3 (continued)

\section{Variable}

Lagged nonwhite population

First difference, nonwhite population

Lagged unemployment rate

First difference, unemployment rate

Lagged female labor force participation

First difference, female labor force participation

Lagged federal government partisan control

First difference, federal government partisan control

Constant
(1)

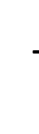

b

b

0.015

0.190

0.002

0.002

$-0.001$

$-0.001$

$-0.002$

$-0.003$

0.313

600
0.398
101.30
0.000

600

101.30

0.000
(2)

b

0.020

0.020
0.252

0.003

0.002

$-0.001$

$-0.001$

$-0.002$

$-0.003$

0.302

$7.33^{* * *}$

600

0.387

98.65

0.000

$\begin{array}{lll}2.91^{* *} & 0.016 & 2.65^{* *} \\ 2.01^{*} & 0.182 & 1.43 \\ & & \\ 3.22^{* * *} & 0.002 & 2.75^{* *} \\ 1.22 & 0.002 & 1.14 \\ & & \\ -1.91^{*} & -0.001 & -2.27^{*} \\ -0.85 & -0.001 & -1.12 \\ & & \\ -0.81 & -0.002 & -0.86 \\ -1.28 & -0.003 & -1.30 \\ & & \\ 7.10^{* * *} & 0.314 & 7.31^{* * *}\end{array}$

Prob (Wald $\chi^{2}$ )

$* * *$ prob $<0.001 \quad * * \quad$ prob $<0.01 \quad * \quad$ prob $<0.05$

$* * *$ prob $<0.001 \quad * * \quad$ prob $<0.01 \quad * \quad$ prob $<0.05$
600

0.399

104.05

0.000 


\section{REFERENCES}

Alderson, Arthur S., and François Nielsen. (2002). Globalization and the Great U-Turn: Income Inequality Trends in 16 OECD Countries. American Journal of Sociology, 107(5), 1244-1299. doi: 10.1086/341329

Altonji, Joseph, and Card, David. (1991). The Effects of Immigration on the Labor Market Outcomes of Lessskilled Natives. In J. Abowd and R. B. Freeman (Eds.), Immigration, Trade and the Labor Market (pp. 201-234). Chicago: University of Chicago Press.

Alvarez, R. M., and Bedolla, L. García. (2003). The Foundations of Latino Voter Partisanship: Evidence from the 2000 Elections. Journal of Politics, 65(1), 31-49.

Atkinson, Anthony B. (2003). Income Inequality in OECD Countries: Data and Explanations. Paper presented at the Presented at CESifo Conference on Globalization, Inequality and Well-being, Nov. 2002.

Bartels, Larry. (2008). Unequal Democracy: The Political Economy of the New Gilded Age. New Jersey: Princeton University Press.

Bartels, Larry. (2009). Income Inequality and Political Representation. In L. a. D. K. Jacobs (Ed.), The Unsustainable American State (pp. 167-196). New York: Oxford University Press.

Benard, A. B. , and Jensen, JB. . (1998). Understanding Increasing and Decreasing Wage Inequality. National Bureau of Economic. Res. Cambridge. MA.

Benard A. B. and Jensen, JB. . (1998). Understanding Increasing and Decreasing Wage Inequality. National Bureau of Economic. Res. Cambridge. MA.

Berry, William D. , Ringquist, Evan J. , Fording, Richard C. , and Hanson, Russell L. . (1998). Measuring Citizen and Government Ideology in the American States, 1960-93. American Journal of Political Science, 42(1), 327-348.

Borjas, George J. (1994). The Economics of Immigration. Journal of Economic Literature 32, 1667-1717.

Borjas, George J. (2000). Issues in the economics of immigration. Chicago: University of Chicago Press.

Borjas, George J. (2004). Increasing the Supply of Labor Through Immigration: Center for Immigration Studies.

Camarota, Steven A. . (2012). Immigrants in the United States. A Profile of America's Foreign-Born Population.

Card, David. (1990). The Impact of the Mariel Boatlift on the Miami Labor Market. Industrial and Labor Relations Review, 43(2), 245-257.

Card, David. (2007) How Immigration Affects U.S. Cities. Vol. CDP No 11/07. London: Center for Research and Analysis of Migration.

Card, David. (2009). Immigration and Inequality. Paper presented at the January 2009 meeting of the American Economic Association.

Chevan, Albert, and Stokes, Randall. (2000). Growth in Family Income Inequality, 1970-1990 Industrial Restructuring and Demographic Change. Demography, 37(3), 365-380.

Crenshaw, Edward, and Ameen, Ansari (1994). The Distribution of Income Across National Populations: Testing Multiple Paradigms. Social Science Research, 23, 1-22.

De Boef, Suzanna. (2001). Modeling equilibrium relationships: Error correction models with strongly autoregressive data. Political Analysis, 9(1), 78-94.

De Boef, Suzanna, and Granato, Jim (1997). Near-integrated data and the analysis of political relationships. American Journal of Political Science, 41(4), 619-640.

De Boef, Suzanna, and Keele, Luke (2008). Taking time seriously. American Journal of Political Science 52(1), 184-200.

DeNavas-Walt, Carmen and Bernadette D. Proctor. (2014). Income and Poverty in the United States: 2013. https://www.census.gov/content/dam/Census/library/publications/2014/demo/p60-249.pdf. 
Dooley, M. , and Gottschalk, P. (1985). The Increasing Proportion of Men with Low Earnings in the United States. Demography, 22, 25-34.

Fording, Richard C. (1997). The Conditional Effect of Violence as a Political Tactic: Mass Insurgency, Welfare Generosity, and Electoral Context in the American States. American Journal of Political Science 41: 1-29.

Garand, James. (2010). Income Inequality, Party Polarization, and Roll-Call Voting in the U.S. Senate. Journal of Politics, 72(4), 1109-1128.

Goldin, Claudia Dale, and Katz, Lawrence F. (2008). The race between education and technology. Cambridge, Mass.: Belknap Press of Harvard University Press.

Gottschalk, P. (1997). Inequality, Income growth, and mobility: the basic facts. Journal of economic perspectives(11), 21-40.

Grant, DS., and Wallace, M. . (1994). The political economy of manufacturing growth and decline across the American states,1970-1985. Social Forces, 73(33).

Guetzkow, Joshua, Bruce Western, and Jake Rosenfeld. (2007). State-Level Data on Income Inequality: 1963-2003.

Hacker, Jacob, and Pierson, Jeffrey G. . (2010). Winner-Take-All Politics: How Washington Made the Rich Richer and Turned Its Back on the Middle Class. New York: SimonandSchuster Paperbacks.

Hanson, Gordon H. (2004). Immigration Policy.

Hatton, T. J., and Williamson, Jeffrey G. (1998). The age of mass migration : causes and economic impact. New York: Oxford University Press.

Hainmueller, Jens and Michael J. Hiscox. (2010). Attitudes toward Highly Skilled and Low-skilled Immigration: Evidence from a Survey Experiment. American Political Science Review 104: 61-84.

Hero, Rodney E. , and Preuhs, Robert R. . (2007). Immigration and the Evolving American Welfare State: Examining Policies in the U.S. States. American Journal of Political Science 51(3), 498-517.

Hirsch, B.T. . (2012). Unionstats: Union Membership and Coverage Database from the CPS.

Hoefer, Michael, Rytina, Nancy, and Baker, Bryan. (2011). Estimates of the Unauthorized Immigrant Population Residing in the United States: January 2011. In D. O. o. I. Statistics (Ed.), Population Estimates.

Jacobs, Lawrence R. and Skocpol, Theda (2005). Inequality and American democracy: what we know and what we need to learn. New York: Russell Sage Foundation.

Kelly, Nathan J., and Enns, Peter K. . (2010). Inequality and the Dynamics of Public Opinion: The SelfReinforcing Link Between Economic Inequality and Mass Preferences. The American Journal of Political Science, 54(4), 855-870.

Kelly, Nathan, and Kelly, Jana Morgan (2005). Religion and Latino Partisanship in the United States. Political Research Quarterly, 58, 87-95.

Kelly, Nathan. (2009). The Politics of Income Inequality in the United States. New York, NY.: Cambridge University Press.

Kelly, Nathan. J., and Witko, Christopher. (2012). Federalism and American Inequality. Journal of Politics, 74(2), 414-426.

Kuznets, Simon. (1955). Economic Growth and Income Inequality. American Economic Review, 45, 1-28.

Kuznets, Simon. (1953). Shares of Upper Income Groups in Income and Savings (pp. 327-362). New York: National Bureau of Economic Activity.

Lerman, Robert I. (1999). U. S. Wage-Inequality Trends and Recent Immigration. The American Economic Review, 89(2), 23-28.

Levy, Frank, and Temin, Peter (2007). Inequality and Institutions in 20th Century America. MIT Department of Economics Working Paper \#07-17. 
Malhotra, Neil, Yotam Margolit, and Cecilia Hyunjung Mo. (2013). Economic Explanations for Opposition to Immigration: Distinguishing between Prevalence and Conditional Impact. American Journal of Political Science 57: 391-410.

McCarty, Nolan M., Poole, Keith T., and Rosenthal, Howard. (2006). Polarized America : the dance of ideology and unequal riches. Cambridge, Mass.: MIT Press.

Moore, E. G., and Pacey, M. A. (2003). Changing income inequality and immigration in Canada, 1980-1995. Canadian Public Policy-Analyse De Politiques, 29(1), 33-52.

Nielsen, FranSois, and Alderson, Arthur S. (1997). The Kuznets Curve and the Great U-turn: Patterns of Income Inequality in United States Counties, 1970-1990. American Sociological Review, 62, 12-33.

Passel, Jeffrey S. 2005. (2005). Estimates of the Size and Characteristics of the Undocumented Population. Research Report of the Pew Hispanic Center. Washington, DC: Pew Hispanic Center.

Preuhs, Robert R. (2007). Descriptive Representation as a Mechanism to Mitigate Policy Backlash: Latino Incorporation and Welfare Policy in the American States. Political Research Quarterly 60: 277-92.

Putnam, Robert. (2000). Bowling Alone: The Collapse and Revival of American Community. New York: SimonandSchuster.

Reed, Deborah. (2001). Immigration and Males' Earnings Inequality in the Regions of the United States. Demography, 38(3), 363-373.

Reeves, Richard. V., and Venator, Joanna. (2014). Immigration and the American Dream, Part 1. Retrieved from http://www.brookings.edu/blogs/social-mobility-memos/posts/2014/06/19-immigrationamerican-dream-reeves website:

Richardson, J. David. (1995). Income Inequality and Trade: How to Think, What to Conclude. Journal of Economic Perspectives, 9(3), 33-55.

Rodwin, L., and Sazanami, H. (1991). Industrial Change and Regional Economic Transformation: The Experience of Western Europe. London: HarperCollins Academic.

Ryan, Camille. L., and Siebens, Julie. (2012). Educational Attainment in the United States: 2009. In U. C. Bureau (Ed.), (Vol. P20-566).

Skocpol, Theda. (2003). Diminished Democracy: From Membership to Management in American Civic Life. Norman: University of Oklahoma Press.

Solt, Frederick. (2008). Economic Inequality and Democratic Political Engagement. American Journal of Political Science, 52(1), 48-60.

Soss, Joe, and Jacobs, Laurence (2010). The Politics of Inequality in America: A Political Economy Framework. Annual Review of Political Science, 13, 341-364.

Thurow, Lester C. (1987). A Surge in Inequality. Scientific American, 256, 30-37.

Treas, Judith. (1987). The Effect of Women's Labor Force Participation on the Distribution of Income in the United States. Annual Review of Sociology, 13, 259-288.

Williamson, Jeffrey G. (1997). Globalization and Inequality, Past and Present. The World Bank Rearch Observer, 12(2), 117-135. 


\section{APPENDICES}

\section{Appendix 1: Interpreting the Effects of Newly-Admitted Legal Permanent Residents}

We note that the coefficients for the newly-admitted LPR variable must be interpreted with care. Because newly admitted LPRs are encompassed within the foreign-born population variable, the coefficient for the newly admitted LPRs represents the difference in the effects of LPRs and the effect of the non-LPR foreign-born population. Specifically, our full model of the effects of immigration on income inequality looks like this:

$$
\text { Income inequality } \left.=a+b_{1} \text { (Foreign-born population }\right)+b_{2}(\text { LPRs })+\text { controls }
$$

However, the foreign-born population variable actually includes LPRs, as well as the remaining individuals who are part of the foreign-born population. We can break out these two groups thusly:

Income inequality $=a+b_{1}($ Other foreign-born population + LPRs $)+b_{2}($ LPRs $)+$ controls

Rearranging the terms:

Income inequality $=a+b_{1}$ (Other foreign-born population) $+b_{1}$ (LPRs) $+b_{2}$ (LPRs) + controls

We can now collect terms to generate the following equation, which reveals the appropriate interpretation of the coefficients for these three variables:

Income inequality $=a+b_{1}$ (Other foreign-born population) $+\left(b_{1}+b_{2}\right)($ LPRs $)+$ controls

Given this, $b_{1}$ represents the effect on income inequality of other foreign-born population (i.e., non-new LPRs), and $b_{2}$ represents the difference in the effect for the foreign-born population and new LPRs. The question is whether or not new LPRs have an additional effect on income inequality above and beyond the effect of the general foreign-born population. 
Appendix Figure A1: Time trends for average Gini coefficients of income inequality and the size of foreign-born population, 1996-2008.

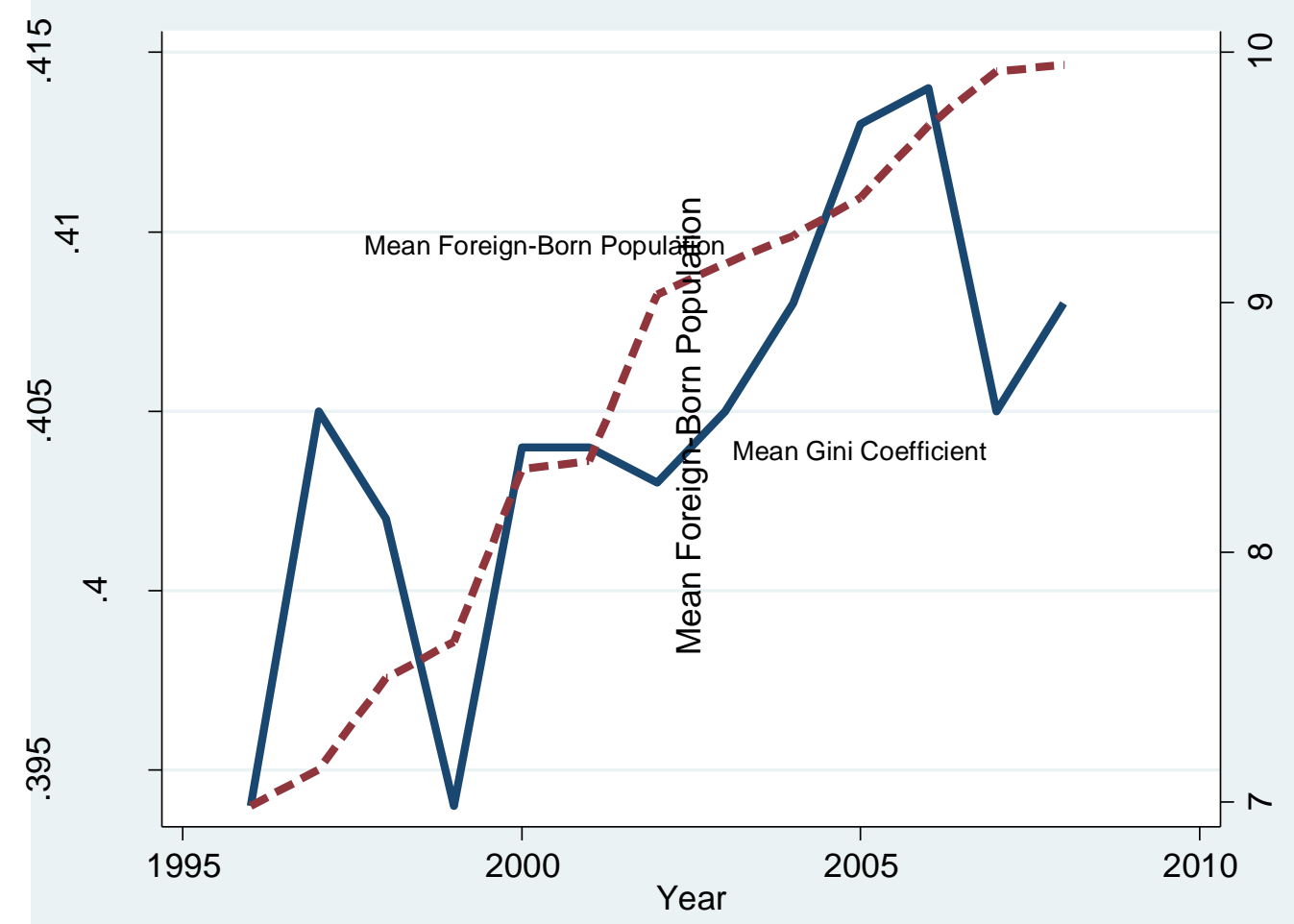

$r=0.723$ 
Table A1. Panel corrected standard error (PCSE) estimates of effect of immigration on change in various income ratios, dynamic estimates, 1996-2008

\begin{tabular}{|c|c|c|c|c|c|c|}
\hline \multirow[b]{2}{*}{ Variable } & \multicolumn{2}{|c|}{ 90/10 Ratio } & \multicolumn{2}{|c|}{ 90/50 Ratio } & \multicolumn{2}{|c|}{ 50/10 Ratio } \\
\hline & $\mathrm{b}$ & z & $\mathrm{b}$ & z & $\mathrm{b}$ & z \\
\hline Lagged income ratio & -0.619 & $-9.12 * * *$ & -0.718 & $-9.71 * * *$ & -0.670 & $-9.19 * *$ \\
\hline Lagged foreign-born population & 0.017 & $2.11^{*}$ & 0.006 & $2.91 * *$ & 0.000 & 0.11 \\
\hline First difference, foreign-born population & -0.036 & -1.14 & -0.009 & -1.51 & -0.003 & -0.30 \\
\hline Newly-admitted legal permanent residents & -0.432 & -1.39 & -0.084 & -1.31 & -0.088 & -1.05 \\
\hline Lagged union density & -0.012 & $-2.55 * *$ & -0.005 & $-4.30 * * *$ & 0.000 & 0.22 \\
\hline First difference, union density & -0.007 & -0.26 & 0.001 & 0.12 & -0.003 & -0.34 \\
\hline Lagged state government liberalism & 0.001 & 0.72 & 0.000 & -0.55 & 0.000 & 1.48 \\
\hline First difference, state government liberalism & 0.004 & 1.63 & 0.000 & 0.44 & 0.001 & 1.80 \\
\hline Lagged real per capita income & 0.001 & 0.12 & 0.002 & 0.95 & -0.001 & -0.28 \\
\hline First difference, real per capita income & 0.095 & $2.70^{* *}$ & 0.007 & 1.16 & 0.030 & $2.62 * *$ \\
\hline Lagged manufacturing & 0.092 & 0.19 & 0.045 & 0.42 & -0.072 & -0.46 \\
\hline First difference, manufacturing & 3.952 & $-1.70^{*}$ & -0.591 & -1.16 & -1.057 & -1.37 \\
\hline Lagged college graduates & 2.414 & $3.10 * * *$ & 0.394 & $2.34 * *$ & 0.567 & $2.32 * *$ \\
\hline First difference, college graduates & 2.434 & 1.29 & 0.605 & $1.71 *$ & 0.178 & 0.28 \\
\hline
\end{tabular}


Table A1 (continued)

\begin{tabular}{|c|c|c|c|c|c|c|}
\hline \multirow[b]{2}{*}{ Variable } & \multicolumn{2}{|c|}{ 90/10 Ratio } & \multicolumn{2}{|c|}{ 90/50 Ratio } & \multicolumn{2}{|c|}{ 50/10 Ratio } \\
\hline & $b$ & z & $b$ & z & $\mathrm{b}$ & z \\
\hline Lagged nonwhite population & 0.845 & $3.17 * * *$ & 0.151 & $2.82 * *$ & 0.200 & $2.73^{* *}$ \\
\hline First difference, nonwhite population & 7.263 & $2.24 *$ & 1.746 & $2.46 * *$ & 0.729 & 0.75 \\
\hline Lagged unemployment rate & 0.122 & $4.16 * * *$ & 0.008 & 1.60 & 0.046 & $4.72 * * *$ \\
\hline First difference, unemployment rate & 0.006 & 0.15 & -0.002 & -0.21 & 0.002 & 0.20 \\
\hline Lagged female labor force participation & -0.021 & $-2.74 * *$ & -0.010 & $-6.42 * * *$ & 0.003 & 1.11 \\
\hline First difference, female labor force participation & -0.028 & -1.16 & -0.013 & $-2.62 * *$ & 0.008 & 0.85 \\
\hline Lagged federal government partisan control & -0.031 & -0.65 & -0.019 & $-1.70^{*}$ & 0.017 & 1.09 \\
\hline First difference, federal government partisan control & 0.063 & 1.90 & 0.004 & 0.51 & 0.025 & $2.33^{*}$ \\
\hline Constant & 4.374 & $5.38 * * *$ & 2.044 & $8.46 * * *$ & 1.550 & $5.21 * * *$ \\
\hline $\mathrm{N}$ & \multicolumn{2}{|c|}{637} & \multicolumn{2}{|c|}{637} & \multicolumn{2}{|c|}{637} \\
\hline $\mathrm{R}^{2}$ & \multicolumn{2}{|c|}{0.383} & \multicolumn{2}{|c|}{0.405} & \multicolumn{2}{|c|}{0.384} \\
\hline Wald $\chi^{2}$ & \multicolumn{2}{|c|}{155.38} & \multicolumn{2}{|c|}{135.05} & \multicolumn{2}{|c|}{123.50} \\
\hline Prob (Wald $\chi^{2}$ ) & \multicolumn{2}{|c|}{0.000} & \multicolumn{2}{|c|}{0.000} & \multicolumn{2}{|c|}{0.000} \\
\hline
\end{tabular}

$* * *$ prob $<0.001 * *$ prob $<0.01 \quad * \quad$ prob $<0.05$ 
Table A2. Panel corrected standard error (PCSE) estimates of effect of immigration on change in various income ratios for the 90th percentile, dynamic estimates, 1996-2008

\begin{tabular}{|c|c|c|c|c|c|c|c|c|}
\hline \multirow[b]{2}{*}{ Variable } & \multicolumn{2}{|c|}{ 90/10 Ratio } & \multicolumn{2}{|c|}{ 90/20 Ratio } & \multicolumn{2}{|c|}{ 90/30 Ratio } & \multicolumn{2}{|c|}{ 90/40 Ratio } \\
\hline & $\mathrm{b}$ & z & $\mathrm{b}$ & z & $\mathrm{b}$ & z & $\mathrm{b}$ & z \\
\hline Lagged income ratio & -0.619 & $-9.12 * * *$ & -0.590 & $-8.37 * * *$ & -0.654 & $-8.96 * * *$ & -0.686 & $-9.35 * * *$ \\
\hline Lagged foreign-born population & 0.017 & $2.11^{*}$ & 0.011 & $2.35^{* *}$ & 0.010 & $2.99 * *$ & 0.008 & $3.53 * * *$ \\
\hline First difference, foreign-born population & -0.036 & -1.14 & -0.028 & -1.74 & -0.019 & -1.86 & -0.018 & $-2.36^{*}$ \\
\hline Newly-admitted legal permanent residents & -0.432 & -1.39 & -0.270 & -1.62 & -0.175 & -1.45 & -0.142 & -1.75 \\
\hline Lagged union density & -0.012 & $-2.55^{* *}$ & -0.009 & $-3.85 * * *$ & -0.009 & $-4.98 * * *$ & -0.007 & $-4.78 * * *$ \\
\hline First difference, union density & -0.007 & -0.26 & -0.009 & -0.64 & -0.005 & -0.55 & -0.001 & -0.18 \\
\hline Lagged state government liberalism & 0.001 & 0.72 & 0.000 & 0.45 & 0.000 & 0.01 & 0.000 & 0.06 \\
\hline First difference, state government liberalism & 0.004 & 1.63 & 0.001 & 0.79 & 0.001 & 1.36 & 0.001 & 1.19 \\
\hline Lagged real per capita income & 0.001 & 0.12 & 0.003 & 0.61 & 0.001 & 0.51 & 0.001 & 0.72 \\
\hline First difference, real per capita income & 0.095 & $2.70 * *$ & 0.040 & $2.29 *$ & 0.024 & $2.02 *$ & 0.018 & $2.21 *$ \\
\hline Lagged manufacturing & 0.092 & 0.19 & 0.096 & 0.55 & 0.008 & 0.05 & 0.061 & 0.48 \\
\hline First difference, manufacturing & -3.952 & $-1.70^{*}$ & -2.214 & $-1.80 *$ & -1.867 & $-2.09 *$ & -1.261 & $-1.99 *$ \\
\hline Lagged college graduates & 2.414 & $3.10 * * *$ & 1.347 & $3.19 * * *$ & 0.882 & $2.85^{* *}$ & 0.593 & $2.84^{* *}$ \\
\hline First difference, college graduates & 2.434 & 1.29 & 1.792 & $1.99 *$ & 1.375 & $2.11^{*}$ & 0.999 & $2.05^{*}$ \\
\hline
\end{tabular}


Table A2 (continued)

\begin{tabular}{|c|c|c|c|c|c|c|c|c|}
\hline \multirow[b]{2}{*}{ Variable } & \multicolumn{2}{|c|}{ 90/10 Ratio } & \multicolumn{2}{|c|}{ 90/20 Ratio } & \multicolumn{2}{|c|}{ 90/30 Ratio } & \multicolumn{2}{|c|}{ 90/40 Ratio } \\
\hline & $\mathrm{b}$ & z & $\mathrm{b}$ & z & $\mathrm{b}$ & $\mathrm{z}$ & $\mathrm{b}$ & $\mathrm{z}$ \\
\hline Lagged nonwhite population & 0.845 & $3.17 * * *$ & 0.481 & $3.65 * * *$ & 0.307 & $2.94 * *$ & 0.227 & $3.20 * * *$ \\
\hline First difference, nonwhite population & 7.263 & $2.24 *$ & 5.438 & $2.93 * *$ & 3.467 & $2.91^{* *}$ & 3.172 & $3.78 * * *$ \\
\hline Lagged unemployment rate & 0.122 & $4.16 * * *$ & 0.047 & $3.78 * * *$ & 0.034 & $3.87 * * *$ & 0.018 & $2.84 * *$ \\
\hline First difference, unemployment rate & 0.006 & 0.15 & 0.011 & 0.54 & 0.010 & 0.79 & 0.007 & 0.76 \\
\hline Lagged female labor force participation & -0.021 & $-2.74 * *$ & -0.015 & $-3.58 * * *$ & -0.012 & $-4.61 * * *$ & -0.011 & $-5.80 * * *$ \\
\hline First difference, female labor force participation & -0.028 & -1.16 & -0.030 & $-2.40 * *$ & -0.021 & $-2.44 * *$ & -0.018 & $-3.01 * *$ \\
\hline Lagged federal government partisan control & -0.031 & -0.65 & -0.043 & -1.37 & -0.041 & $-2.11^{*}$ & -0.034 & $-2.57^{* *}$ \\
\hline First difference, federal government partisan control & 0.063 & 1.90 & 0.040 & 1.76 & 0.017 & 1.20 & 0.004 & 0.41 \\
\hline Constant & 4.374 & $5.38 * * *$ & 2.954 & $6.02 * * *$ & 2.570 & $6.98 * * *$ & 2.320 & $7.62 * * *$ \\
\hline $\mathrm{N}$ & & 637 & & 637 & & 637 & & 637 \\
\hline $\mathrm{R} 2$ & & 0.383 & & 0.355 & & 0.385 & & 0.403 \\
\hline Wald $\chi 2$ & & 155.38 & & 144.71 & & 145.03 & & 164.65 \\
\hline Prob (Wald $\chi 2$ ) & & 0.000 & & 0.000 & & 0.000 & & 0.000 \\
\hline
\end{tabular}


Table A3. Panel corrected standard error (PCSE) estimates of effect of high- and low-skill immigration on change in various income ratios, dynamic estimates, 1996-2008

\begin{tabular}{|c|c|c|c|c|c|c|}
\hline \multirow[b]{2}{*}{ Variable } & \multicolumn{2}{|c|}{ 90/10 Ratio } & \multicolumn{2}{|c|}{ 90/50 Ratio } & \multicolumn{2}{|c|}{ 50/10 Ratio } \\
\hline & $\mathrm{b}$ & z & $\mathrm{b}$ & z & $\mathrm{b}$ & z \\
\hline Lagged income ratio & -0.633 & $-7.71 * * *$ & -0.753 & $-9.42 * * *$ & -0.655 & $-8.06 * * *$ \\
\hline Lagged low-skill foreign-born population & 0.039 & $3.63 * * *$ & 0.015 & $5.32 * * *$ & -0.001 & -0.26 \\
\hline First difference, low-skill foreign-born population & -0.008 & -0.17 & -0.005 & -0.61 & 0.003 & 0.22 \\
\hline Lagged high-skill foreign-born population & -0.047 & -1.45 & -0.016 & $-2.65 * *$ & -0.002 & -0.21 \\
\hline First difference, high-skill foreign-born population & -0.023 & -0.36 & -0.026 & $-2.12^{*}$ & 0.027 & 1.32 \\
\hline Lagged union density & -0.011 & $-1.94^{*}$ & -0.003 & $-3.26 * * *$ & -0.001 & -0.41 \\
\hline First difference, union density & -0.004 & -0.14 & 0.003 & 0.57 & -0.005 & -0.56 \\
\hline Lagged state government liberalism & 0.001 & 0.79 & 0.000 & -0.35 & 0.000 & 1.38 \\
\hline First difference, state government liberalism & 0.002 & 0.98 & 0.000 & 0.02 & 0.001 & 1.37 \\
\hline Lagged real per capita income & -0.001 & -0.07 & 0.003 & 1.59 & -0.003 & -0.82 \\
\hline First difference, real per capita income & 0.104 & $2.76 * *$ & 0.008 & 1.21 & 0.031 & $2.60 * *$ \\
\hline Lagged manufacturing & -0.061 & -0.12 & -0.007 & -0.06 & -0.053 & -0.38 \\
\hline First difference, manufacturing & -2.413 & -0.89 & -0.405 & -0.82 & -0.673 & -0.78 \\
\hline Lagged college graduates & 2.878 & $2.67 * *$ & 0.635 & $3.02 * *$ & 0.511 & $1.74^{*}$ \\
\hline First difference, college graduates & 2.949 & 1.38 & 0.709 & $1.94^{*}$ & 0.231 & 0.32 \\
\hline
\end{tabular}


Table A3 (continued)

\begin{tabular}{|c|c|c|c|c|c|c|}
\hline \multirow[b]{2}{*}{ Variable } & \multicolumn{2}{|c|}{ 90/10 Ratio } & \multicolumn{2}{|c|}{ 90/50 Ratio } & \multicolumn{2}{|c|}{ 50/10 Ratio } \\
\hline & $\mathrm{b}$ & z & $\mathrm{b}$ & z & $\mathrm{b}$ & z \\
\hline Lagged nonwhite population & 0.937 & $3.43^{* * *}$ & 0.191 & $3.59 * * *$ & 0.189 & $2.42 * *$ \\
\hline First difference, nonwhite population & 5.482 & 1.41 & 1.420 & $1.76^{*}$ & 0.535 & 0.61 \\
\hline Lagged unemployment rate & 0.115 & $4.00 * * *$ & 0.005 & 1.10 & 0.044 & $4.53 * * *$ \\
\hline First difference, unemployment rate & 0.011 & 0.28 & -0.003 & -0.42 & 0.007 & 0.64 \\
\hline Lagged female labor force participation & -0.018 & -1.41 & -0.011 & $-4.30 * * *$ & 0.004 & 1.38 \\
\hline First difference, female labor force participation & -0.003 & -0.10 & -0.010 & $-2.02 *$ & 0.014 & 1.53 \\
\hline Lagged federal government partisan control & -0.003 & -0.06 & -0.013 & -1.10 & 0.018 & 1.08 \\
\hline First difference, federal government partisan control & 0.080 & 1.77 & 0.006 & 0.65 & 0.028 & $2.35^{*}$ \\
\hline Constant & 4.324 & $4.69 * * *$ & 2.097 & $7.97 * * *$ & 1.517 & $5.03 * * *$ \\
\hline $\mathrm{N}$ & \multicolumn{2}{|c|}{650} & \multicolumn{2}{|c|}{650} & \multicolumn{2}{|c|}{650} \\
\hline $\mathrm{R}^{2}$ & \multicolumn{2}{|c|}{0.353} & \multicolumn{2}{|c|}{0.405} & \multicolumn{2}{|c|}{0.360} \\
\hline Wald $\chi^{2}$ & \multicolumn{2}{|c|}{98.56} & \multicolumn{2}{|c|}{119.76} & \multicolumn{2}{|c|}{91.93} \\
\hline Prob (Wald $\chi^{2}$ ) & \multicolumn{2}{|c|}{0.000} & \multicolumn{2}{|c|}{0.000} & \multicolumn{2}{|c|}{0.000} \\
\hline
\end{tabular}

$* * *$ prob $<0.001 * *$ prob $<0.01 \quad * \quad$ prob $<0.05$ 
Table A4. Panel corrected standard error (PCSE) estimates of effect of high- and low-skill immigration on change in various income ratios for the 90th percentile, dynamic estimates, 1996-2008

\begin{tabular}{|c|c|c|c|c|c|c|c|c|}
\hline \multirow[b]{2}{*}{ Variable } & \multicolumn{2}{|c|}{ 90/10 Ratio } & \multicolumn{2}{|c|}{ 90/20 Ratio } & \multicolumn{2}{|c|}{ 90/30 Ratio } & \multicolumn{2}{|c|}{ 90/40 Ratio } \\
\hline & $b$ & z & $\mathrm{b}$ & z & $\mathrm{b}$ & z & $\mathrm{b}$ & z \\
\hline Lagged income ratio & -0.633 & $-7.71 * * *$ & -0.621 & $-7.98 * * *$ & -0.680 & $-8.81 * * *$ & -0.722 & $-9.08 * * *$ \\
\hline Lagged low-skill foreign-born population & 0.039 & $3.63 * * *$ & 0.031 & $4.21 * * *$ & 0.024 & $4.71 * * *$ & 0.020 & $5.57 * * *$ \\
\hline First difference, low-skill foreign-born population & -0.008 & -0.17 & -0.006 & -0.25 & -0.008 & -0.45 & -0.018 & -1.51 \\
\hline Lagged high-skill foreign-born population & -0.047 & -1.45 & -0.045 & $-2.52 * *$ & -0.026 & $-2.02 *$ & -0.024 & $-2.80 * *$ \\
\hline First difference, high-skill foreign-born population & -0.023 & -0.36 & -0.060 & -1.71 & -0.030 & -1.30 & -0.027 & -1.70 \\
\hline Lagged union density & -0.011 & $-1.94 *$ & -0.007 & $-2.71 * *$ & -0.007 & $-4.00 * * *$ & -0.006 & $-3.80 * * *$ \\
\hline First difference, union density & -0.004 & -0.14 & -0.005 & -0.40 & -0.002 & -0.24 & 0.001 & 0.19 \\
\hline Lagged state government liberalism & 0.001 & 0.79 & 0.000 & 0.74 & 0.000 & 0.13 & 0.000 & 0.11 \\
\hline First difference, state government liberalism & 0.002 & 0.98 & 0.000 & 0.31 & 0.001 & 0.91 & 0.000 & 0.66 \\
\hline Lagged real per capita income & -0.001 & -0.07 & 0.005 & 1.01 & 0.003 & 1.13 & 0.003 & 1.42 \\
\hline First difference, real per capita income & 0.104 & $2.76^{* *}$ & 0.042 & $2.43 * *$ & 0.023 & $2.08 *$ & 0.018 & $2.25^{*}$ \\
\hline Lagged manufacturing & -0.061 & -0.12 & 0.004 & 0.02 & -0.082 & -0.47 & -0.006 & -0.04 \\
\hline First difference, manufacturing & -2.413 & -0.89 & -1.664 & -1.31 & -1.484 & $-1.67^{*}$ & -0.947 & -1.51 \\
\hline Lagged college graduates & 2.878 & $2.67 * *$ & 1.957 & $3.44 * * *$ & 1.301 & $3.21 * * *$ & 0.967 & $3.46 * * *$ \\
\hline First difference, college graduates & 2.949 & 1.38 & 2.137 & $2.21 *$ & 1.414 & $2.00 *$ & 1.006 & $2.01 *$ \\
\hline
\end{tabular}


Table A4 (continued)

\begin{tabular}{|c|c|c|c|c|c|c|c|c|}
\hline \multirow[b]{2}{*}{ Variable } & \multicolumn{2}{|c|}{ 90/10 Ratio } & \multicolumn{2}{|c|}{ 90/20 Ratio } & \multicolumn{2}{|c|}{ 90/30 Ratio } & \multicolumn{2}{|c|}{ 90/40 Ratio } \\
\hline & $\mathrm{b}$ & z & $\mathrm{b}$ & z & $\mathrm{b}$ & $\mathrm{z}$ & $b$ & z \\
\hline Lagged nonwhite population & 0.937 & $3.43 * * *$ & 0.562 & $4.23 * * *$ & 0.378 & $3.65 * * *$ & 0.290 & $4.17 * * *$ \\
\hline First difference, nonwhite population & 5.482 & 1.41 & 4.451 & $1.94 *$ & 2.884 & $2.27^{*}$ & 2.734 & $3.10 * * *$ \\
\hline Lagged unemployment rate & 0.115 & $4.00 * * *$ & 0.043 & $3.31 * * *$ & 0.031 & $3.64 * * *$ & 0.015 & $2.48 * *$ \\
\hline First difference, unemployment rate & 0.011 & 0.28 & 0.010 & 0.50 & 0.009 & 0.68 & 0.006 & 0.66 \\
\hline Lagged female labor force participation & -0.018 & -1.41 & -0.017 & $-2.87 * *$ & -0.014 & $-3.68 * * *$ & -0.013 & $-4.04 * * *$ \\
\hline First difference, female labor force participation & -0.003 & -0.10 & -0.022 & $-1.76^{*}$ & -0.016 & $-1.91^{*}$ & -0.014 & $-2.21^{*}$ \\
\hline Lagged federal government partisan control & -0.003 & -0.06 & -0.027 & -0.78 & -0.030 & -1.53 & -0.026 & $-1.92^{*}$ \\
\hline First difference, federal government partisan control & 0.080 & 1.77 & 0.048 & 1.78 & 0.022 & 1.53 & 0.008 & 0.75 \\
\hline Constant & 4.324 & $4.69 * * *$ & 3.031 & $5.79 * * *$ & 2.614 & $6.83^{* * *}$ & 2.393 & $7.25 * * *$ \\
\hline $\mathrm{N}$ & & 650 & & 650 & & 650 & & 650 \\
\hline $\mathrm{R} 2$ & & 0.353 & & 0.349 & & 0.375 & & 0.397 \\
\hline Wald $\chi 2$ & & 98.56 & & 115.85 & & 122.85 & & 145.77 \\
\hline Prob (Wald $\chi 2$ ) & & 0.000 & & 0.000 & & 0.000 & & 0.000 \\
\hline
\end{tabular}

$* * *$ prob $<0.001 \quad * *$ prob $<0.01 \quad * \quad$ prob $<0.05$ 